\title{
THEORETICAL ASPECTS OF THE EMPLOYEES' RIGHT TO UNPAID LEAVE
}

\author{
I. Stancea
}

\author{
Isabela Stancea \\ Department of Administrative Sciences, Law and Communication, \\ "Constantin Brancoveanu” University Piteşti, Piteşti, Romania, \\ *Correspondence: Isabela Stancea, Constantin Brancoveanu University, Calea Bascovului, \\ no. 2, Piteşti, Romania, \\ Email: stanceaiza@yahoo.com
}

\begin{abstract}
The right to unpaid leave is a benefit for the employee, a time during which he/she can solve certain personal problems, during an established period of time, without losing the position of employee, but also as a disadvantage for the employer, as he/she is obliged to pursue the same activity, for a certain period of time, with fewer employee.
\end{abstract}

Keywords: unpaid leave, employee, employer, agreement, employment contract.

\section{Introduction}

During the unpaid leave the employment contract is suspended, and if through the applicable collective agreement or through other special laws more favorable rights are not provided, the employees will not receive subscription for employment.

About the unpaid leave, the rule is that it does not represent job seniority, since for this term the employer has no social security contribution. As an exception, unpaid leave for professional training represents job seniority but does not generate a contribution period.

Of all the rights enjoyed by a person, naturally, only in the virtue of being a human being, only the right to work seems to be the most complex and controversial. More complex, because on its existence depend other rights, such as: the right to remuneration for the work performed, the right to daily and weekly rest, the right to equal opportunities and treatment, the right to paid annual vacation, to dignity at work, the right to safety and health at work, the right of access to training, the right to information and consultation, the right to participate in collective actions, etc. and it is controversial because although framed as a real right in Article 41 of the Constitution, it must be perceived as an obligation, for example, the Fundamental Law, in Article 56 "Financial Contributions" stipulates that citizens have the obligation to contribute through taxes and duties to public expenditure. And this obligation can be satisfied only by the right (or obligation) to work.

As shown, the right to work under numerous other rights provided by the Labor Code, other regulations or applicable collective agreements. The right to unpaid leave is a benefit to the employee, in that it can solve personal problems in a period of time without losing an employee, but also as a disadvantage of the employer, as it is obliged to conduct the same activity, for a certain period of time, with fewer employees.

The employee's right to unpaid leave is covered very briefly by the Labor Code. Thus, a slight reference to this form of leave is found for the first time in Article 54, in the chapter on individual labor contract suspension, the leave without pay for education or personal interests appeared as a cause for suspension of contract work by the parties.

As defined, the suspension of the individual labor contract has the effect of rendering the suspension of work by the employee and salary payment default by the employer, but 
during the suspension other rights and obligations of the parties may continue to exist, provided by other regulations, the applicable collective bargaining agreement, individual employment contracts or internal regulations ${ }^{1}$.

So, during the leave without pay the individual labor contract is suspended, and if through the applicable collective labor contract or special laws other favorable rights are not provided, the employees will receive training for employment ${ }^{2}$.

We consider that a shortcoming of this law article would be stipulating a maximum period of leave without pay that an employee could benefit form, but this lack is compensated for later on, in Article 148 of the Labor Code which stipulates that in order to solve personal situations the employees are entitled to time off without pay. The duration of leave without pay is set by the applicable collective labor contract or the by Internal Rules.

In practice questions are often asked about the maximum duration of leave without pay, the conditions in which they may be granted, and whether or not this period is work experience. Social Dialogue Law no. 62/2011, published in the Official Gazette no. 322 of May 10, 2011, a bill that repeals the Law Express. 130/1996, stipulates that collective agreements can be negotiated at the level of units, groups of units or sectors. Therefore, the provisions on leave without pay may differ from one professional category to another.

For instance, Law no. 1/2011 of the National Education provides the teachers holding a teaching position in education, which on their own initiative seek to specialize or participate in scientific research in the country or abroad, are entitled to unpaid leave. Their duration cannot exceed 3 years in a period of seven years. Approvals in these situations are handled by the management institution of higher education or, according to each case, by the Board, if that activity ${ }^{3}$ is proved.

The same bill also provides that full-time teaching staff holding a position in the education system may receive unpaid leave for one academic year, once every 10 years, with the approval of higher education institution, with the reservation of the position during that period. As it is natural, the whole period of reservation is considered job seniority or work experience in education and implicitly at work.

We appreciate that this initiative of Law no. 1/2011 is welcome, and even constitutes an incentive for the teachers who want to conduct scientific research in the country or abroad, because they can benefit from professional training and at the same time their teaching position are retained, also benefiting from job seniority. This benefit of the law should help to stimulate scientific research among teachers.

But the permissive nature of this rule has generated in practice situations in which teachers apply for unpaid leave for a period of one year for going abroad in order to conduct other activities unrelated to their profession. In these cases, the ones who have to lose are the students who will have to be prepared by substitute teachers. We believe that it would be necessary to have a legislation to hinder the right of teachers to have unpaid leave for reasons unrelated to their profession.

Also, the internal regulations of public institutions may provide a certain number of days of leave without pay in full compliance with applicable labor contracts.

Although it is a great right of interest of the employee, most institutions insert through their Internal Regulations terse provisions concerning the employee's right to unpaid leave, such as: the staff is entitled to unpaid leave under the law. Records of leave without pay will be held by the department of human resources that will pursue their implications on length of service. Most often, however, by internal regulations employers provide a total of 30 days of

\footnotetext{
${ }^{1}$ http://e-juridic.manager.ro/articole/concediu-fara-plata-drepturile-si-obligatiile-salariatilor--5757.html ${ }^{2} \mathrm{http} / / /$ legislatiamuncii.manager.ro/a/2645/concediu-fara-plata-drepturile-si-obligatiile-salariatilor.html ${ }^{3}$ Article 304 paragraph 10 of Law no. 1/2011 of the National Education published in the Official Gazette Part I no. 18 of 10 January 2011.
} 
unpaid leave per year that the employee is entitled to, without mentioning whether or not these days are considered job seniority, a fact which gave rise in practice to many abuses by employers, especially under the old legislation.

Another bill that inserts in its content the employee's right to unpaid leave is the Government Decision no. 250/1992 updated. It provides in Article 25 paragraph (1) that the employees from public administration, from the autonomous bodies and from the budgetary units are entitled to time off without pay whose total duration may not exceed 90 days annually, to solve the following personal situations.

The enactment also provides what these personal situations are, as follows ${ }^{4}$ :

a) passing the school-leaving exam, the examination for admission to institutions of higher education or extramural evening classes, examinations of the academic year, as well as graduation exams for employees who attend a form of higher education, evening classes or without attendance;

b) passing the exam for admission to doctoral examinations or doctoral thesis, for employees who do not receive doctoral grants;

c) presentation in the contest to fill a position in another unit.

It is also stipulated in the same normative act that this professional category is entitled to unpaid leave without the limit of 90 days in the cases above-mentioned in the following situations:

a) caring for a sick child older than 3 years, in the period indicated in the medical certificate, both the mother and the father employed can benefit from this right, if the mother of the child does not benefit, for the same reasons, from leave without pay;

b) medical treatment abroad performed during the period prescribed by the doctor, if the person in question is not entitled by law to compensation for temporary disability, as well as for accompanying the spouse or a close relative - child, brother, sister, parent, during treatment abroad - in both cases with the approval of the Ministry of Health ${ }^{5}$.

Therefore, the employee is entitled to unpaid leave which can exceed the limit of the 90 days given that the leave is necessary to care for sick children aged 3 years or to carry out treatment abroad.

Also, Government Decision no. 250/1992 also provides that the conditions for the leave without pay may also be granted for personal interests, other than those mentioned above, for duration determined by the parties' agreement, and during these holidays, the people involved are maintained as employees.

Indeed, in the absence of a uniform legal provision, in practice some employers have granted long-term unpaid leave (one year or even for an indefinite period, but determinable) in the case of certain employees with a particular family situation or with a very good professional training.

In the same bill ${ }^{6}$, the legislator provides that in case the leave without pay is granted for a period of 90 days, respectively in the situations in which the employee requires unpaid leave for the baccalaureate exam, the examination for admission to institutions of education, evening classes or extramural, academic year examinations, graduation, the employee's length of service is not affected, making it clear that in the case of leave longer than 90 days, the length of service will be affected.

This law article seems discriminatory: if an employee in the education system has his/her length of service acknowledged for unpaid leave for a period of one year, it would be

\footnotetext{
${ }^{4}$ G.O. no. $250 / 1992$ on annual leave and other leave of employees of public administration, particularly in specific autonomous units and the budget published in the Official Gazette of no. 118 of June 13, 1995, Article 25 paragraph (2).

${ }^{5}$ Ibidem

${ }^{6}$ Ibidem, Article 25 paragraph (1) a.
} 
normal to be the same for the employee in the public or from other fields, the length of service should be acknowledged for the same period, and not just for 90 days. We appreciate that a uniform legislation is necessary in this field, which does not create differentiated situations for each professional group separately.

Most collective labor agreements at units' group level provide that the employees are entitled to 30 calendar days of paid or unpaid leave, to support a one-time diploma examination in higher education and the foremen and 60 calendar days leave without pay to pass higher education exam sessions, with or without attendance. Some collective agreements at units' group level provide that this leave may be granted and divided. Through the collective work agreements one may grant other types of leave without pay, whose duration cannot exceed 90 working days.

There are, nevertheless, collective work agreements at branch level that provide a number of days of unpaid leave of up to 60 days with the approval, as it should be, of the management unit. In these cases there is no mention either if during this form of leave the employee benefits form job seniority or the situations in which such a leave may be approved. We appreciate the need for such clarification in order to avoid individual work conflicts between employee and employer.

If the period of leave without pay is not stipulated by the applicable collective labor contract or the internal regulation the person who will decide on this issue for each case will be the employer ${ }^{7}$.

And for the professional training, the Labor Code provides that the employee is entitled to request leave with or without pay.

In the case of the leave without pay for professional training, it is given only at the request of the employee, during the vocational training period that is attended on his/her own initiative. The employer may refuse the request of the employee only if the employee's absence would seriously damage the activity.

And this provision of the law could create harm to the employee who - being unable to prove that his/her absence from work may be substituted by another employee and cannot cause serious harm to the employer - could be deprived of the benefit of unpaid leave when it is necessary to pass the graduation exam or other examinations.

On the other hand, in order to avoid abuse of rights by the employee who may request unpaid leave unduly, the employer is entitled to appraise the merits of the employee's request, through the analysis of the personal situation, the analysis of the consequences that could yield a refusal on his part, including the taking into consideration of the unit's interests ${ }^{8}$.

Article 151 of the Labor Code provides that the request for unpaid leave for professional training must be submitted to the employer at least one month before its performance and it shall specify the start date of the internship training, its duration as well as the name of the training institution. The logic of this approach is that it enables the employer to find another person to replace someone that left on unpaid leave.

Taking the leave without pay for professional training can also be divided through division during a calendar year for the final exams of some forms of higher education or to pass some promotion examinations in the next academic year in the higher education institutions?.

About the training of the employee, the Labor Code provides that if the employer has not complied with the obligation to ensure on his/her expense the participation of an

\footnotetext{
${ }^{7}$ Ioan Ciochina-Barbu-Law. University course, Hamangiu Publishing House, 2012, page 236.

${ }^{8}$ Daniela Moțiu individual labor-law, CHBeck Publishing House, Bucharest, 2011, page 321.

${ }^{9}$ Cristina Radu Roxana- Labor Law. Theoretical and practical considerations. Vol II, Alma Publishing House, Craiova, 2006, page 40 .
} 
employee in the professional training as provided by law, the employee is entitled to leave for professional training, paid by the employer, up to 10 working days or up to 80 hours.

The duration of the leave for the professional training cannot be deducted from the duration of the annual leave and it is associated to a period of actual work in terms of entitlements of the employee, other than the salary ${ }^{10}$. We understand from the text of the law that the leave without pay for professional training represents job seniority.

As shown above, the leave without pay is one of the causes of suspension of the individual labor contract at the initiative of both parties. The initiative of the leave without pay must belong to the employee, but it is absolutely necessary, according to the principle of mutual consent in the work legal relationships, to have the employer's consent. Therefore, at least in theory, the leave without pay at the employer's initiative cannot exist, just because the purpose of such a leave is for the employee to solve some personal problems. In practice, under the old legislation, there have been situations in which the employers sent all or part of employees on leave without pay, for a certain period of time, in case he/she did not have the opportunity to ensure they work.

To prevent recurrence of such situations, but also to help employers, the Labor Code modified in 2011 expressly regulates such cases in Article 52 paragraph (3) as follows: "in case of temporary reduction of activity, for economic, technological, structural or similar reasons, on periods exceeding 30 working days, the employer will be able to reduce the working hours from 5 to 4 days per week, with the corresponding reduction in salary, to remedy the situation that caused the reduction of the program, after the previous consultation of the representative union of the unit or of representative employee, as appropriate".

In practice, the question often arises if the leave without pay is similar to the permission. The answer is that, the leave without pay is not the same with the permission ${ }^{11}$.

Although there is no legal provision to regulate it expressly, the permission is the situation in which the employee is absent from work, with the written consent of employer and with payment of salary. Permission does not affect length of service and it can last a period of hours, up to one working day.

There are situations in which the employer has the obligation to give permission to the employee, such as when the employee is called as a witness in criminal or civil lawsuits, or in the case of pregnant female employees who have to go to the doctor ${ }^{12}$.

According to art. 175 paragraph (1) of the Criminal Procedure Code, as amended and supplemented subsequently, the calling of a person before a criminal investigation body or the court shall be made by written summons. The summoning can also be done by telephone or telegraph note. In this case, the employer cannot oppose the permission and the salary during the absence from work for such situations is stipulated by the Code of Criminal Procedure.

Also, according to Government Ordinance no. 111/2010 on parental leave and monthly parental allowance, Article 6 paragraph (1), after the child reaches the age of one year, except for children with disabilities, the people who have opted for parental leave and monthly allowance of 600 lei are entitled to unpaid parental leave for raising the child until he/she turns 2 years old.

During the time the female employee is on this type of leave, it will not be possible to terminate her individual employment contract and other people shall not be employed on her position, except with fixed-term work contract ${ }^{13}$.

\footnotetext{
${ }^{10}$ Article 153 of Labor Code.

${ }^{11} \mathrm{http} / / /$ legislatiamuncii.manager.ro/a/1891/concediul-fara-plata-constituie-sau-nu-vechime-in-munca.html.

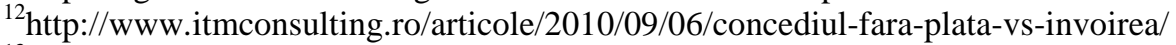

${ }^{13}$ Cristina Radu Roxana Law. Theoretical and practical considerations. Vol II, Alma Publishing House, Craiova, 2006, page 39.
} 
The leave granted under these conditions represents a right of the employee, which makes the granting of the leave be an obligation for the employer ${ }^{14}$.

The request for granting leave without pay for child allowance shall be filed and recorded in the employer based on family book or birth certificate of the child.

People that in the last year before the child's birth were on sick leave also benefit from these rights, or who attended full-time university courses or who have received unemployment.

As a summary, the parents who chose the one-year leave for raising the child, are given the possibility by this this bill to monitor child raising by being on parental leave without pay until the child reaches the age of 2 .

\section{Conclusions}

In terms of leave without pay, the rule is that it is not length of service, this time because during this period the employer does not contribute to the social security system. By exception, the leave without pay for professional training represents job seniority, but does not generate contribution period.

Also, another exception is the situation in which the law provides that in determining the 12 months to achieve the last year taxable income also include the period of the leave without pay for professional training at the employer's initiative or with his/her consent ${ }^{15}$, and if parental leave without compensation.

Situations of unpaid leave in the private sector are left by the legislator on the account of agreement between the parties, so they can be provided in the applicable collective labor contract or in the internal regulation, cases and conditions for granting them ${ }^{16}$.

\section{Bibliography}

Ciochină- Barbu I., Labor law. University course, Bucharest, Hamangiu Publishing House, 2012;

Dacian D., Chiciudean R., Emrich G., Labor law. University course, "Babeş-Bolyai”" University, Cluj-Napoca, 2012;

Moțiu D., Individual labor law, C.H. Beck Publishing House, Bucharest, 2011;

Radu C.R., Labor law. Theoretical and practical considerations, Vol. II, Alma Publishing House, Craiova, 2006;

Voiculescu N., Labor law. Course Notes. Domestic and international regulations, Dacia Europa Nova Publishing House, Lugoj, 2001;

\section{Normative acts}

Law no. 1/2011 of the National Education published in the Official Gazette of Romania, Part I no. 18 of 10 January 2011;

Government Decision No. 250/1992 on annual leave and other leaves of employees in public administration, particularly in special statute companies and budgetary units published in the Official Gazette of Romania, no.118 of June 13, 1995;

Labor Code in reprinted 2011;

G.E.O no.148/2005 on supporting the family in child-raising updated text based on modifying legal acts published in the Official Gazette, Part I, from December 31, 2008.

\footnotetext{
${ }^{14}$ Nicolae Voiculescu-Law. Course Notes. Domestic and international regulations, Europe Dacia Nova Publishing House, Lugoj, 2001, page 163.

${ }^{15}$ GEO no. 148/2005 on family support in child raising, updated text modifying the legal acts published in the Official Gazette, Part I, to December 31, 2008 Article 1, paragraph (2).

${ }^{16}$ Daniela Moțiu individual labor-law, C.H. Beck Publishing House, Bucharest, 2011, page 321.
} 


\section{Web sources:}

- $\quad$ http://e-juridic.manager.ro/articole/concediu-fara-plata-drepturile-si-obligatiilesalariatilor--5757.html;

- $\quad$ http://legislatiamuncii.manager.ro/a/2645/concediu-fara-plata-drepturile-si-obligatiilesalariatilor.html;

- $\quad$ http://legislatiamuncii.manager.ro/a/1891/concediul-fara-plata-constituie-sau-nuvechime-in-munca.html;

- $\quad$ http://www.itmconsulting.ro/articole/2010/09/06/concediul-fara-plata-vs-invoirea. 